\begin{tabular}{|c|c|c|}
\hline $\begin{array}{l}\text { 2. ro: (Receiving organization) } \\
\text { Distribution }\end{array}$ & $\begin{array}{l}\text { 3. From: (originating Organization) } \\
\text { Mechanical Systems Design }\end{array}$ & $\begin{array}{r}\text { 4. Related EDT No.: } \\
N / A\end{array}$ \\
\hline $\begin{array}{l}\text { 5. Proj./Prog./Dept./Div.: } \\
\text { 94C-EWW-369/Hydrogen } \\
\text { Monitoring/8C } 460 / \text { N2068 }\end{array}$ & $\begin{array}{l}\text { 6. Cog. Engr.: } \\
\text { TC Schneider }\end{array}$ & $\begin{array}{l}\text { 7. Purchase order No.: } \\
\qquad N / A\end{array}$ \\
\hline \multirow{2}{*}{\multicolumn{2}{|c|}{$\begin{array}{l}\text { 8. Originator Remarks: } \\
\text { (ETN-96-023) } \\
\text { This functional design criteria document is being } \\
\text { transmitted for review, approval and release. }\end{array}$}} & $\begin{array}{l}\text { 9. Equip./Component No.: } \\
\text { N/A }\end{array}$ \\
\hline & & $\begin{array}{r}\text { 10. System/Bldg./Facility: } \\
241 \text { General }\end{array}$ \\
\hline \multirow{3}{*}{\multicolumn{2}{|c|}{ 11. Receiver Remarks: }} & $\begin{array}{c}\text { 12. Major Assm. Owg. No.: } \\
\text { N/A }\end{array}$ \\
\hline & & $\begin{array}{l}\text { 13. Permit/Permit Application No.: } \\
N / A\end{array}$ \\
\hline & & $\begin{array}{l}\text { 14. Required Response Date: } \\
7-11-97\end{array}$ \\
\hline
\end{tabular}

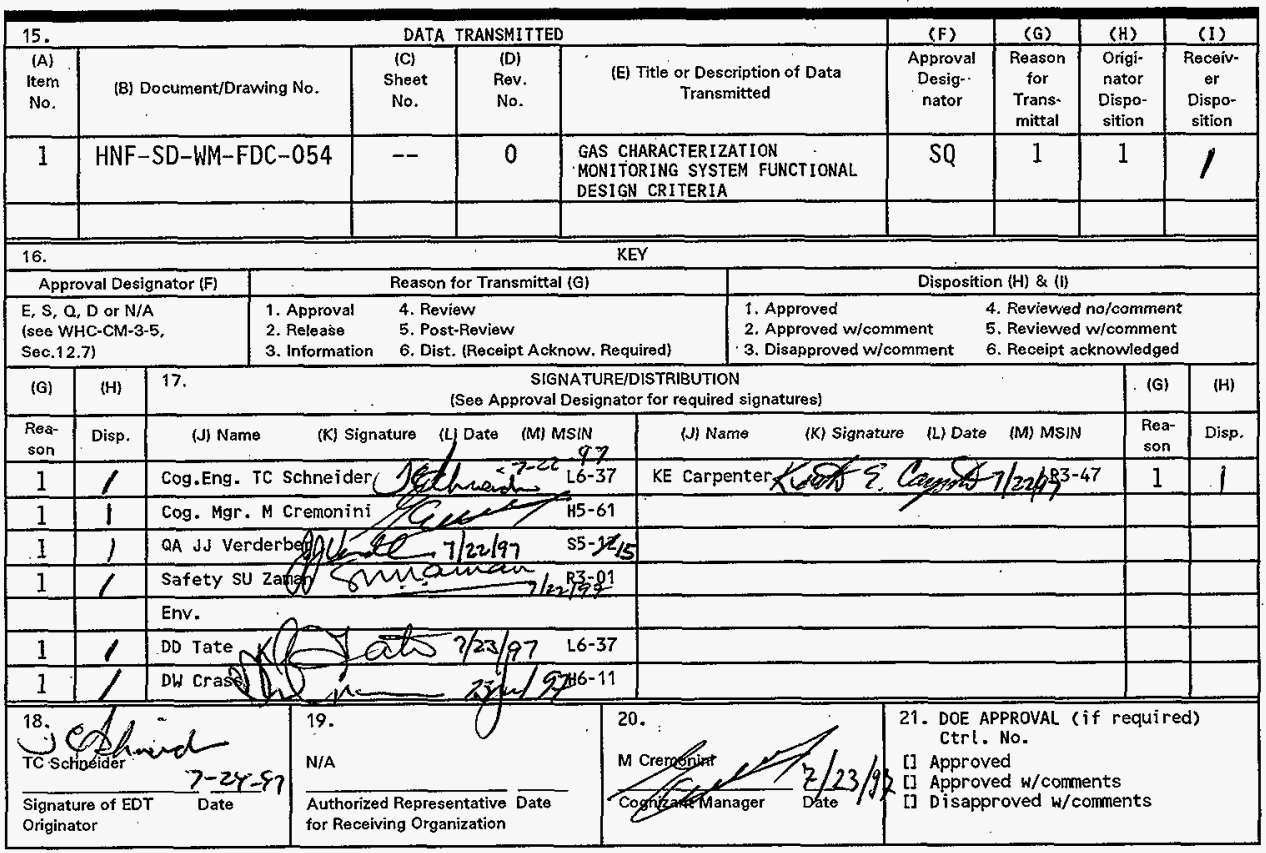




\section{GAS CHARACTERIZATION MONITORING SYSTEM FUNCTIONAL DESIGN CRITERIA}

\section{TC Schneider}

Numatec Hanford Corporation, Richland, WA 99352

U.S. Department of Energy Contract DE-AC06-96RL13200

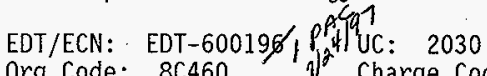

Org Code: 8C460 ㄱ Charge Code: $N 2022$

B\&R Code: EW3120072 Total Pages: 14

Key Words: Gas Monitoring, Gas Characterization, Hydrogen Monitoring, Standard Hydrogen Monitoring System, SHMS-E

Abstract: The purpose of this document is to provide the functional design criteria for the Gas Characterization Monitoring Systems (Standard-E Hydrogen Monitoring Systems) to be designed, fabricated and installed on the Waste Tank Farms in the Hanford 200 Areas.

TRADEMARK DISCLAIMER. Reference herein to any specific commercial product, process, or service by trade name, trademark, manufacturer, or otherwise, does not necessarily constitute or imply its endorsement, recommendation, or favoring by the United States Government or any agency thereof or its contractors or subcontractors.

Printed in the United States of America. To obtain copies of this document, contact: WHC/BCS Document Control Services, P.O. Box 1970, Majlstop H6-08, Richland WA 99352, Phone (509) 372-2420; Fax (509) 376-4989.
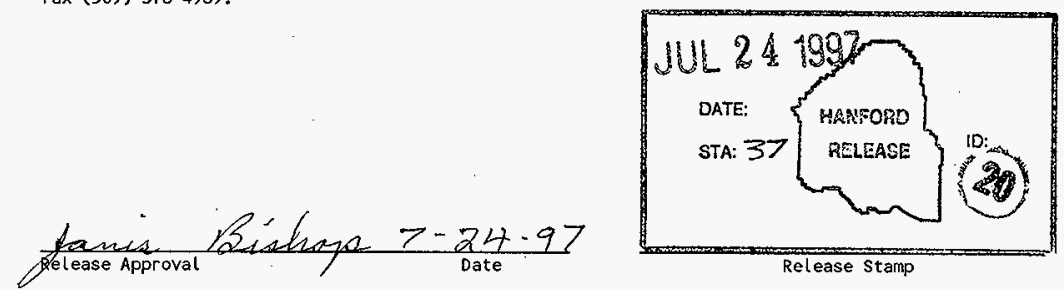
HNF-SD-WM-FDC-054

Rev. 0

Page 1

GAS CHARACTERIZATION MONITORING SYSTEM

FUNCTIONAL DESIGN CRITERIA

Rev. 0

APPROVAL DESIGNATOR SQ

T.C. Schneider

Mechanical Systems Design

Numatec Hanford Corporation, Richland Wa. 99352

U.S. Department of Energy Contract DE-AC06-96RL13200 June, 1997 
HNF-SD-WM-FDC-054

Rev. 0

Page 2

TABLE OF CONTENTS

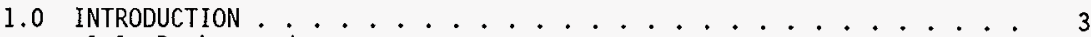

1.1 Background ..................... 3

1.2 Scope .......................... . . . . . . 4

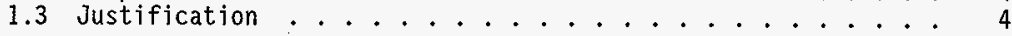

2.0 PROJECT FUNCTIONAL DESCRIPTION . . . . . . . . . . . . . . . . . . 4

3.0 PROCESS DESIGN CRITERIA . . . . . . . . . . . . . . . . . . 5

3.1 Instrumentation and contro] .............. 5

3.2 Piping . . . . . . . . . . . . . . . . . 8

3.3 General Chemical Process . . . . . . . . . . . . . 8

3.4 General Mechanical Process................. . . 9

3.5 Systems Interface ..................... . . . 10

4.0 FACILITY DESIGN CRITERIA . . . . . . . . . . . . . . . 10

4.1 Architectural ..................... . . . . 10

4.2 HVAC ......................... 10

4.3 Electrical . . . . . . . . . . . . . . . . . . . . . 10

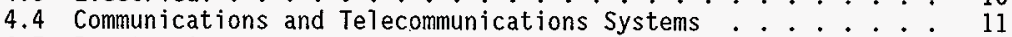

4.5 Penetrations...................... . . . 11

4.6 Compressed Gasses . . . . . . . . . . . . . . . . 11

5.0 GENERAL REQUIREMENTS . . . . . . . . . . . . . . . . . . . 11

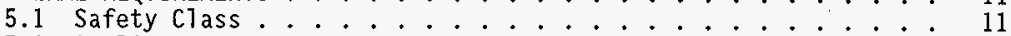

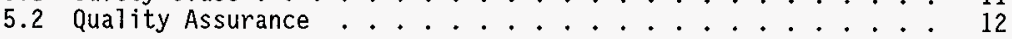

6.0 REFERENCES . . . . . . . . . . . . . . . . . . . . . 12 
HNF-SD-WM-FDC-054

Rev. 0

Page 3

\section{GAS CHARACTERIZATION AND MONITORING SYSTEM FUNCTIONAL DESIGN CRITERIA}

\subsection{INTRODUCTION}

\subsection{Background}

Tank 241-SY-101 (SY-101) is known to experience periodic tank level increases and decreases during which hydrogen gas is released. It is suspected that the generated gases accumulate in the solids-containing layer near the bottom of the tank. The accumulation of gases creates a buoyancy that eventually overcomes the density and cohesive strength of the bottom layer. When this happens, the gas is released upward through the liquid layer and also carries some of the bottom layer upward. This phenomenon is referred to as a Gas Release Event (GRE). Pre-mitigation monitoring of Tank $S Y-101$ indicated release concentrations greater than the lower flammability limit ( $L F L$ ) of hydrogen $\left(H_{2}\right)$ in a hydrogen/nitrous oxide $\left(\mathrm{N}_{2} \mathrm{O}\right)$ atmosphere. Since the mitigation of $\mathrm{SY}-101$ GREs, the measured hydrogen concentrations in the tank vapor space have remained in the low ppm range.

Other waste tanks have been identified as having the potential to behave similar to SY-101. These tanks have been placed on the flammable gas watch list (FGWL) which is continually reevaluated based upon new criteria. It has been determined that all tanks on the FGWL will have a vapor space monitoring system installed to measure hydrogen. These tanks have been equipped with continuous gas monitors called a Standard Hydrogen Monitoring System (SHMS). The SHMS units contain two electrochemical cells which monitor for hydrogen.

In order to meet program and regulatory commitments for continuous gas monitoring and characterization of FGWL tanks with a high probability for a GRE, an expanded flexibility in the gas monjtoring system is needed to measure selected gas species at both high and low concentrations. The purpose of this additional characterization is to determine the actual lower flammability limit of these tanks, to accurately measure low baseline gas release concentrations, and to determine potential hazards associated with larger GREs. For these reasons, a modified version of the Standard Hydrogen Monitoring System (SHMS) is proposed for the new gas monitoring systems. The SHMS-E wi11 be similar to the current systems, with modular, expandable analytical characterization capabilities. 
HNF-SD-WM-FDC-054

Rev. 0

Page 4

\subsection{Scope}

The scope of this functional design criteria (FDC) document is to define the design criteria specific to a Gas Characterization and Monitoring (GCM) system which can be sited at selected FGWL waste tanks. This FDC is based upon and expanded from the original SHMS design criteria provided in WHC-SD-WM-CR-043, Design Requirements and Criteria for a Hydrogen Monitoring System for Tanks 103-SY and 104-AN (Groth 1991).

\subsection{Justification}

Tank SY-101 has one of the highest safety priorities for both the Hanford Site and the U.S. Department of Energy (DOE). However, other waste tanks have been identified as having the potential for GREs which include $\mathrm{H}_{2}, \mathrm{~N}_{2} \mathrm{O}$ and Ammonia $\left(\mathrm{NH}_{3}\right)$. Analyzing the tank vapor space gases is required to determine the magnitude and time dependance of the various gases released from these tanks.

\subsection{Site Location}

Tanks identified as having a "serious potential for release" exceeding the LFL will be candidates for the expanded vapor space analytical quality gas characterization and monitoring. Tank selection is based upon the information captured in HNF-SP-1193, Flammab7e Gas Project Topical Report (Johnson 1997). The GCM enclosures shall be located so that samples can be drawn from the vapor space or exhaust header at the selected tank. Each site location shall be based upon minimal tank sample gas delivery time, power availability, and access to data transmission facilities.

\subsection{PROJECT FUNCTIONAL DESCRIPTION}

The primary function of the $\mathrm{GCM}$ is to provide an environmentally controlled enclosure to sample the identified waste tank's vapor space gasses and analyze the sampled gasses for $\mathrm{H}_{2}$ as well as other suspected gas species which include, but are not 7 imited to methane $\left(\mathrm{CH}_{4}\right), \mathrm{N}_{2} \mathrm{O}$ and $\mathrm{NH}_{3}$.

The GCM shall consist of five major components: the enclosure, the sample gas delivery system, the sample gas monitoring and analytical system, the sample gas grab sample system, and a data acquisition and process control system. The enclosure shall provide a temperature controlled environment to house scientific equipment for the analys is of the waste tank vapor space gases. The sample gas delivery system shall provide a gas sample to the monitoring and analytical systems. The 
HNF-SD-WM-FDC-054

Rev. 0

Page 5

sample gas monitoring and analytical system shall be capable of measuring a wide range of hydrogen concentrations and a variety of other specified gas species, such as $\mathrm{N}_{2} \mathrm{O}, \mathrm{CH}_{4}$ and $\mathrm{NH}_{3}$, from low to high part per million (ppm) concentrations. The grab sample system will provide the capability for independent analysis of a tank gas sample, taken either manually or automatically at a preset $\mathrm{H}_{2}$ concentration level. The data system will store and archive analytical gas monitoring data as well as process variables such as flow and pressure.

The GCM enclosure shall be similar to the already installed SHMS units located on the existing FGWL tanks. The design shall provide, as possible, for a modular addition of analysis hardware to augment the existing electro-chemical monitoring cells. Following the tank characterization phase, the analys is hardware may be removed to provide a normal SHMS monitoring for medium to high hydrogen gas concentrations.

\subsection{PROCESS DESIGN CRITERIA}

\subsection{Instrumentation and Control}

\subsubsection{Instruments, Type, Range, and Accuracy}

The sample gas monitoring and analytical system shall consist of two Whittaker electro-chemical cells, a dual column gas chromatograph and one photo acoustic multi-gas monitor with the following measurement ranges and accuracies for a gaseous mixture consisting primarily of moist air with concentrations of the gasses 1 isted below:

\begin{tabular}{|c|c|c|}
\hline Measured Gas & Range & Accuracy \\
\hline \multirow{3}{*}{$\mathrm{H}_{2}$} & $3-30 \mathrm{ppm}$ & $\pm 3 \mathrm{ppm}$ \\
\cline { 2 - 4 } & $30-3,000 \mathrm{ppm}$ & $\pm 10 \%$ of Reading \\
\cline { 2 - 4 } & $0.2-10.0 \mathrm{Vo} 1 . \%$ & $\pm 0.20 \mathrm{Vol} \%$ \\
\hline \multirow{3}{*}{$\mathrm{CH}_{4}$} & $10-100 \mathrm{ppm}$ & $\pm 10 \mathrm{ppm}$ \\
\cline { 2 - 4 } & $100-4,000 \mathrm{ppm}$ & $\pm 10 \%$ of Reading \\
\hline \multirow{3}{*}{$\mathrm{NH}_{3}$} & $10-100 \mathrm{ppm}$ & $\pm 10 \mathrm{ppm}$ \\
\cline { 2 - 4 } & $100-10,000 \mathrm{ppm}$ & $\pm 10 \%$ of Reading \\
\hline \multirow{3}{*}{$\mathrm{N}_{2} \mathrm{O}$} & $10-30 \mathrm{ppm}$ & $\pm 3 \mathrm{ppm}$ \\
\cline { 2 - 4 } & $30-4,000 \mathrm{ppm}$ & $\pm 10 \%$ of Reading \\
\hline
\end{tabular}


NOTE: Accuracy requirements as stated in this section apply only to the individual instrumentation associated with the hydrogen monitoring system. To determine overall accuracy of any final recorded measurements, the errors introduced by field wiring, wiring termination, signal conditioners, other readout devices, etc. must be added to the values given in this section.

Process instrumentation such as flow, pressure and temperature shall be provided in the ranges and accuracies defined in Section 3.3 .

The sample gas grab sample system will allow a selected gas sample to be captured and taken to a laboratory for independent analysis.

\subsubsection{Repeatability}

The GCM design shall provide systems for daily validations of the gas analysis instruments with selected gas species at one concentration. Analysis instruments will be evaluated for calibration frequency based upon the daily validation readings.

The hydrogen specific monitoring electro-chemical cells will be calibrated quarterly to assure accuracy within the stated requirements.

Engineering process instrumentation shall be able to operate within their prescribed accuracy tolerance for at least one year between calibrations.

\section{$\underline{3.1 .3 \text { Reliability }}$}

Since the gas analysis instrumentation is of a complex and sensitive nature its failure will require replacement of the whole instrument with a "hot" spare, "An instrument which has a proven operating performance in a $1 \mathrm{ab}$ environment with lab gasses." Gas analysis instrumentation for the GCM shall be selected for the best performance and mean time between failure (MTBF) based upon the instrument user data currentiy available.

The process instrumentation sha11 have a MTBF of at least 10,000 hours. 


\subsubsection{Display Requirements}

The gas analytical systems and selected process instrumentation shall provide a local display of the gas analysis performed and selected process engineering parameters.

\subsubsection{Spare Equipment Requirements}

The gas analysis instrumentation requires a "hot" spare complete instrument when a field instrument fails. Thus, at least one spare GC and multi-gas monitor shall be required as "hot" spares to replace field instruments per five (5) GCM enclosures installed.

The process instrumentation shall have one spare for each instrument type for up to ten (10) GCM facilities installed.

\subsubsection{Data Storage and Retrieval}

The host processor for the GCM shall provide for storage of the calculated gas concentrations, spectral data-sets, and calibrations for a period of not less than 7 days. This represents 16 Megabytes per day or 112 megabytes per week. Electronic communication means shall also be provided to accommodate accessing and archiving this data to minimize entering the waste tank farm radiation zones.

Resultant data, defining specific gasses and their concentrations, shall be made electronically available on a file server for access by LANL, LMHC, and PNNL review teams. The resultant data sets, placed on a file server, shall comprise nominally $256 \mathrm{~K}$ bytes per day.

Essential data shall be archived for long term storage (more than one year).

\subsubsection{Software Design Requirements}

Software systems shall utilize vender supplied software and custom developed interfaces. Custom developed software shall be documented and validated per WHC-CM-3-10, Sof tware Practices, Section SP-3.0, "Development" and Section SP-6.0, "Configuration Control". 
HNF-SD-WM-FDC-054

Rev. 0

Page 8

\subsection{Piping}

3.2.1 The sample stream shall be completely contained within piping or instrumentation between the inlet ports on the tank exhaust header or sample port and release back to the exhaust header or tank vapor space.

3.2.2 Devices that come into contact with the sample stream must be qualified or approved for use in a potentially flammable environment.

Those components that come in contact with the sample gas stream within the normal SHMS cabinet have been approved or qualified by the Authority Having Jurisdiction (Per the definitions in NFPA 70, Article 500, Class I, Division 1, Group B).

The analytical components to be used in the gas characterization and monitoring cabinet will be qualified by the Flammable Gas Equipment Advisory Board to analyze tank vapors. This qualification shall comply with the requirements of Standing Order 97-01, Rev. 2 Ignition Control Set (ICS2).

Nonqualified Apparatus (devices not approved for use in the sample gas stream) shall be separated from the sample stream by engineered barriers.

\subsection{General Chemical Process}

The process parameters shall be measured with the following accuracies:

\begin{tabular}{|c|c|}
\hline Measured Parameters & Accuracy \\
\hline Sample Stream Absolute Pressures & $\pm 1 \%$ of Full Scale \\
\hline Differential Pressures & $\pm 1 \%$ of Full Scale \\
\hline Filter Differential Pressures & $\begin{array}{c} \pm \% \text { of Full Scale } \\
\text { (Indication / Status) }\end{array}$ \\
\hline Flow Rates & $\pm 10 \%$ of Full Scale \\
\hline Temperatures & $\pm 4^{\circ} \mathrm{C}$ \\
\hline
\end{tabular}


HNF-SD-WM-FDC-054

Rev. 0

Page 9

\subsection{General Mechanical Process}

The sample gas delivery system shall meet the following requirements:

3.4.1 Provide the ability to draw a tank gas sample under pressures between -12 and +60 inches of water and be able to structural1y withstand temperatures between $-10^{\circ} \mathrm{C}$ and $100^{\circ} \mathrm{C}$ and condensed vapors considered to have a $\mathrm{pH}$ between 8 and 12 .

3.4.2 Provide the sampled gas from the sample point to the hydrogen monitor in less than 30 seconds, to the analytical instruments in less than five minutes and maintain the sample delivery speed upon isolation of any analytical instrument.

3.4.3 Provide two (2) submicron sample gas inlet depth filters inside the enclosure with differential pressure indication.

3.4.4 Provide capability to isolate individual sample line components, as practical, for maintenance.

3.4.5 Provide the necessary fittings, filters, valves, tubing, and sample containers to allow gas samples to be captured and transported to a laboratory for independent analysis.

3.4.6 Provide manual sample gas flow control, with local flow and pressure indication.

3.4.7 Exterior sample gas lines shall be trace heated to maintain a minimum sample temperature of $30^{\circ} \mathrm{C}$ to minimize condensate buildup. Where simple trace heated sample lines are not effective in controlling the gas stream condensate, a gas sample conditioning unit will be employed to control moisture build up within the SHMS enclosure.

3.4.8 Manual sample isolation valves shall be located as close to the tank sample and return points as possible.

3.4.9 Manual isolation valves shall be located in the sample system in such a way to minimize large volumes of trapped gas that would dilute the analyzed sample or calibration gases.

3.4.10 The sample shall not be allowed to vent unfiltered to the environment. 
HNF-SD-WM-FDC-054

Rev. 0

Page 10

\subsection{Systems Interface}

The process instrumentation monitoring the electro-chemical cell outputs, pressure and flow shall interface to the stand-alone data system via 4-20 mA current loops or discrete contact closures. The analytical instrumentation shall have the potential to utilize digital data links to transmit their processed data to remote data storage locations for manipulation, display and recording.

\subsection{FACILITY DESIGN CRITERIA}

\subsection{Architectural}

The design of the enclosure shall meet the requirements for general service structures as specified in DOE 6430.1A and ICFKH A/E STD GCLOAD-01, formerly Standard Design Criteria SDC 4.1. The enclosure shall be designed to maintain the analytical equipment in a clean, dry and mechanically stable environment when the following external conditions exist:

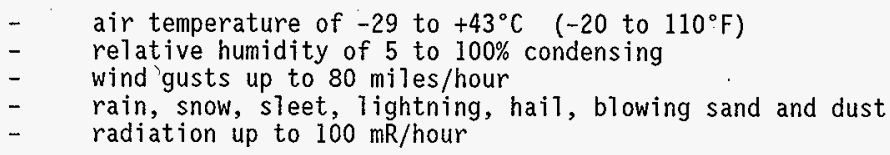

\subsection{HVAC}

The HVAC system must be able to maintain the interior of the enclosure within the instrumentation operating ranges with ail penetrations sealed. Enclosure ambient temperature shall be displayed on a local. digital readout that shall provide a contact closure to the alarm processing PLC for local and remote alarm annunciation.

\subsection{Electrical}

4.3.1 AC power to the computers and process instruments shall be conditioned to reduce voltage surges and electrical noise.

4.3.2 A convenience receptacle protected by a ground fault circuit interrupter shal1 be provided for maintenance support. 
HNF-SD-WM-FDC-054

Rev. 0

Page 11

4.3.3 Inside lighting shall be provided at a level sufficient for personnel to perform general setup and maintenance functions.

4.3.4 Trace heater power shall be protected by a ground fault circuit interrupter.

\subsection{Communications and Telecommunications Systems}

4.4.1 The GCM enclosure shall be provided with a LAN drop via telephone line or other appropriate communications link.

\subsection{Penetrations}

4.5.1 Equipment access shall be by a single door which will be gasketed sufficiently to maintain air and dust inleakage near zero.

4.5.2 Penetrations for electrical power, instruments signals, communications, and instrument gasses shall be through conduits sealed to prevent entry of outside air, dust, and vermin.

\subsection{Compressed Gasses}

4.6.1 An adjacent bottle rack and manifolds shall be provided for compressed gasses which will be used for GC carrier gas and instrument calibrations.

\subsection{GENERAL REQUIREMENTS}

\section{$\underline{5.1 \quad \text { Safety } \mathrm{Class}}$}

The initial standard hydrogen monitoring systems were designated Safety CTass 3 per the requirements of WHC-CM-1-3, MRP 5.46. The GCM has been consistently classified as General Service in accordance with the requirements of WHC-CM-4-46, Safety Analysis Manual, Section 9.0, Table 1 . 
HNF-SD-WM-FDC-054

Rev. 0

Page 12

WHC-SD-WM-BIO-001, TWRS Basis for Interim Operation, addresses the SHMS operation in the tank farms. Although, with the exception of the SHMS on SY-101 associated with mixer pump operation, the SHMS function does not require it to be safety class or safety significant. Its interface to the tank vapor space (a safety class system) does indicate a need for potential spark source isolation. Defense in depth may necessitate designation of some protective equipment as Safety Equipment List components.

\subsection{Quality Assurance}

Documentation associated with the design and construction of the GCM shall be prepared and verified in accordance with WHC-IP-1026, Engineering Practice Guidelines, EPG-2.0, "Engineering System Design Control". The documentation has been assigned Approval Designator $S Q$ for purposes of document approval. This is based on the requirements of WHC-CM-3-5, Document Contro7 and Records Management Manual, Section 12.7, "Approval of Environmental, Safety, and Quality Affecting Documents".

The facility design shall be developed to include the Quality Assurance (QA) requirements in accordance with the project Quality Assurance Program Plan (QAPP). The QAPP shall be consistent with WHC-SD-W369QAPP-01, W-369 Project Specific Quality Assurance Plan, developed for the previous SHMS fabrication and installation activities. The QAPP shall comply with 10 CFR 830.120, "Nuclear Safety Management," as implemented in WHC-SP-1131, WHC Quality Assurance Program and Implementation Plan (Moss 1995).

\subsection{REFERENCES}

6.1 WHC-CM-3-10, Software Practices, Section SP-3.0, "Development" and Section SP-6.0," "Configuration Control"

6.2 WHC-CM-4-46, Safety Analysis Manua7, Section 9.0, "Safety Classification of Structures, Systems and Components".

6.3 WHC-CM-3-5, Document Contro7 and Records Management Manual, Section 12.7, "Approval of Environmental, Safety, and Quality. Affecting Documents".

6.4 WHC-SD-WM-CR-043, Design Requirements and Criteria for a Hydrogen Monitoring. System for Tanks 103-SY and 104-AN (Groth 1991)

6.5 WHC-IP-1026, Engineering Practice Guidelines, EPG-2.0, "Engineering System Design Control". 
HNF-SD-WM-FDC-054

Rev. 0

Page 13

6.6 WHC-SD-WM-BI0-001, TWRS Basis for Interim Operation

6.7 WHC-SD-W369-QAPP-01, W-369 Project Specific Quality Assurance P7an

6.8. WHC-SP-1131, WHC Quality Assurance Program and Implementation P7an (Moss 1995)

6.9 HNF-SP-1193, Flammable Gas Project Topical Report (Johnson 1997).

6.10 DOE 6430.1A, General Design Criteria 


\section{DISTRIBUTION SHEET}

\begin{tabular}{|c|c|c|c|c|c|}
\hline \multirow{2}{*}{$\begin{array}{l}\text { To } \\
\text { DISTRIBUTION }\end{array}$} & \multirow{2}{*}{\multicolumn{3}{|c|}{$\begin{array}{l}\text { From } \\
\text { Mechanical Systems Design }\end{array}$}} & \multicolumn{2}{|c|}{ Page 1 of 1} \\
\hline & & & & \multicolumn{2}{|c|}{ Date June 27,1997} \\
\hline \multirow{2}{*}{\multicolumn{4}{|c|}{$\begin{array}{l}\text { Project Title/Work Order } \\
\text { 94C-EWW-369, Hydrogen Monitoring / N2068 }\end{array}$}} & \multirow{2}{*}{\multicolumn{2}{|c|}{$\begin{array}{ll}\text { EDT No. } & 600191 \\
\text { ECN No. } & \text { N/A }\end{array}$}} \\
\hline & & & & & \\
\hline Name & MSIN & $\begin{array}{l}\text { Text } \\
\text { With All } \\
\text { Attach. }\end{array}$ & Text Only & $\begin{array}{l}\text { Attach./ } \\
\text { Appendix } \\
\text { Only }\end{array}$ & $\begin{array}{l}\text { EDT/ECN } \\
\text { Only }\end{array}$ \\
\hline $\begin{array}{l}\text { KE Carpenter } \\
\text { DW Crass } \\
\text { M Cremonini } \\
\text { MF Erhart } \\
\text { SE Hulsey } \\
\text { GD Johnson } \\
\text { TC Schneider } \\
\text { DD Tate } \\
\text { SU Zaman }\end{array}$ & $\begin{array}{l}\text { R3-47 } \\
H 6-11 \\
H 5-61 \\
\text { R1-51 } \\
\text { R3-08 } \\
\text { S7-15 } \\
\text { L6-37 } \\
\text { L6-37 } \\
\text { R3-01 }\end{array}$ & $\begin{array}{l}X \\
X \\
X\end{array}$ & & & $\begin{array}{l}x \\
x \\
x\end{array}$ \\
\hline Central Files & A3-88 & $x$ & & & \\
\hline
\end{tabular}

